BARTOSZ POKORSKI

University of Łódź

Institute of Philosophy

\title{
AN ATTEMPT TO UPDATE EDWARD DEMBOWSKI'S PHILOSOPHY OF CREATION
}

\begin{abstract}
The article mainly discusses Edward Dembowski's philosophy of creation in connection with his Hegelian influences, leftist associations and the ongoing discussion in nineteenth century romantic polish philosophy. The nineteenth century, with its German Idealism and French tendency to act in the name of social rights, had introduced new ideas to work with during harsh historical times. Dembowski, amongst other Poles, was the closest to constructing a coherent metaphysical system for the philosophy of creation (filozofia twórczości). In the paper, I try to show a part of his intellectual evolution, stretching from defining philosophy as knowledge itself in the form of a Hegelian system, through his critique of Hegel's and Cieszkowski's systems, up to his own established system - the philosophy of creation and its social connections. I also speculate about which of his philosophical ideas can remain relevant today.
\end{abstract}

Keywords. Polish philosophy, philosophy of action, philosophy of creation, German Idealism, nineteenth century romantic philosophy, messianism.

Why Polish Philosophy Does Not Exist is the title of Barry Smith's article in which the author discusses the problem of "Continental Philosophy" and scientific philosophy. He describes the first one in contrast to the philosophical purity of Polish Philosophy that held a strong connection with logic and science. Kazimierz Twardowski had a great influence on that tradition. He encouraged his disciples to study mathematics and science, and instilled a passion for clarity, rigor and seriousness. ${ }^{1}$ These ventures were part of an attempt to create "collaboration between mathematicians and philosophers working in the area of logic" in Lvov at the beginning of the twentieth century. In addition to that, logic, and mathematics with its scientific objectivity, stood outside the political discourse so they could be taught regardless of current political system. It's important to say that Smith understands by Polish Philosophy the one made by thinkers living at least after the year 1894, that will be later known as the LvovWarsaw School. However, he distinguishes this group only to show that the term Polish Philosophy is a misnomer, an inaccurate designation. Kotarbiński's

\footnotetext{
${ }^{1}$ SMITH [2006], p. 26.

${ }^{2}$ Ibid., p. 24.
} 
philosophical solutions were equal to Brentano's; their thoughts are philosophies per se. The Viena Circle was also at "the rise of scientific philosophy [which] is an inevitable concomitant of the simple process of modernization". ${ }^{3}$ That is mainly why Polish Philosophy is, according to Smith, Austrian Philosophy. It is all a part of an inevitable, unifying process.

The demarcation line drawn by Smith is quite clear. Everything except the above mentioned obtains the problematic status of "Continental Philosophy" and is involved in scandal. This includes Hegelian, Heideggerian and Habermasian thought, as well as Deriddian and Irigarian. ${ }^{4}$ These types of thinkers have their moment of unity which is "antipathy to science, or more generally, antipathy to learning and to scholarly activity, to all the normal bourgeois purposes of the Western university" ${ }^{\prime 5}$ as Smith ironically states. It's a philosophy that heavily uses irony and pseudo-scientific jargonizing language inspired by sociology and psychoanalysis. He announces that empirical, more scientific philosophy, rather than German idealism tradition, constitutes the contemporary mainstream. ${ }^{6}$

However, this proposal is the result of a self-proclaimed establishment of the title of the real philosophy determined by active participation in the scientific, academic discourse. Thus, it defines its place in close relation to Science. Smith tries to depreciate Polish efforts to project any fertile thought other than an analytical one. The attempts of Polish romantic thinkers and writers were allegedly "overwhelmed by more forward-looking (...) 'positivists' in Warsaw". While he neglects the role of the early nineteenth century Polish philosophical attempts to introduce philosophical reflection about nation and society on a wider scale, he simultaneously favors late nineteenth century logic and positivist traces which will emerge in the twentieth century Lvov-Warsaw School.

Even if we agreed with some of Smith's critiques of contemporary "Continental Philosophy" his inaccurate and too general definition of "Continental Philosophy" is created only in opposition to science-oriented philosophy that, on its own, has no understanding of itself. Also, he misses at least two points. Firstly, what he calls a philosophical scandal is the type of discussion conducted independently, beyond ordinary, well-established scholarly interests. He narrows the problem of philosophy to a purely academic value. Secondly, although he tries to be respectful of different points of view, he is still very attached to the analytical perspective, which is highly promoted. He does not transcend his own scientific

\footnotetext{
${ }^{3}$ Ibid., p. 34.

${ }^{4}$ Ibid., p. 36.

${ }^{5}$ Ibid., p. 19.

${ }^{6}$ Ibid., p. 33.

${ }^{7}$ Ibid., p. 32.

${ }^{8}$ Sometimes in its ambiguity and hyper relativization it is hard to find accurate meaning.
} 
perspective to ask a philosophical question about philosophy itself. He assumes that the philosophical future in science is self-explanatory. I disagree with the statement that there is no Polish philosophy and also that a philosophical future can only be marked and determined by "a simple process of modernization". Those intellectual eras that are discarded without a second thought by the author as attempts which are not philosophical enough triggered to the ones he refers to as philosophies per se. The question about our present, and consequently our future, is also a question of our relation to the past.

In The Legend of Young Poland, Polish thinker Stanisław Brzozowski states something different, opposite even to Smith's thought. He says that the way we - Poles - treat our own intellectual tradition is scandalous. Brzozowski writes between 1906 and 1909 that Polish romanticism is still unknown to us. We still have to understand and interpret its spiritual atmosphere. ${ }^{9}$ It's not about empty curiosity. Young Poland tried to understood itself via its interpretation of romantic thought; it was the ground work. They were lured by the distorted and fatalistic aspects of romanticism. ${ }^{10}$ Brzozowski was well aware ${ }^{11}$ that Young Poland saw romanticism in its appearance on the stage of history, which was only a superficial understanding. We need to understand that concepts of freedom, independence or Volksgeist, were acts of their life; they emerged from the need to create independent national intellectual ground. Nineteenth century intellectuals wanted to see themselves as the creators of tamed historical forces. Polish writers and thinkers, detached exiles from intellectual ground, had their own practical and common goal: to create, based exclusively on their own individual spirits, a national, intellectual base on which they could build their self-consciousness. ${ }^{12}$ Despite all flamboyant intentions they needed external philosophical inspirations.

Edward Dembowski ${ }^{13}$ in his Outlines of the developing of philosophical concepts in Germany states: "There are two (...) nations that cultivate philosophy: Germany and France, but each of them, in their own proper spirit, separately develop their field of thought". ${ }^{14}$ He states that Slavs are only at the beginning of their philosophical journey. ${ }^{15}$ The development of Polish thought went in two main directions: the German abstract, idealistic and metaphysical tradition, and the French practical tradition, the tendency to apply ideas directly

\footnotetext{
${ }^{9}$ BRZOZOWSKI [1910], p. 192.

${ }^{10}$ Ibid., p. 195.

${ }^{11}$ Ibid., p. 213.

12 Ibid., p. 205.

${ }^{13}$ Polish philosopher, literary critic, and activist, also called the red castellan's-son, organizer of an unsuccessful Cracow Uprising, lived between 1822 and 1846, died at $27^{\text {th }}$ of February in Pogórze Cracow shot by Austrian soldiers.

${ }^{14}$ DEMBOWSKI [1955], p. 298.

${ }^{15}$ Ibid., p. 295.
} 
into socio-economic context. The first one was associated with post-Kantian, mainly Hegelian thought, and gave birth to attempts to create a national philosophy (Trentowski, Libelt). The latter, with political doctrines such as millenarianism, gave birth to its Polish equivalent - messianism (Mickiewicz, Słowacki). ${ }^{16}$ The third way was the combination of those two (Cieszkowski, Dembowski).

Polish messianism was firmly rooted in the contemporary Europe intellectual context. ${ }^{17}$ Not only Poland, but also France was called The Christ of Nations. ${ }^{18}$ The idea of anew revelation and everlasting peace was often associated with deep social changes that could be achieved by a certain task. Count August Cieszkowski directly calls it the philosophy of action. ${ }^{19}$ However, the ways this task can be realized are significantly different. Mickiewicz's position shows an intuitive attitude towards earthly salvation, whereas Cieszkowski thinks that without theoretical reflexion, action is worthless. All of those programs were realized, almost wholly, in the context of history. Thus historiosophy, as a philosophy, tries to understand the past and to project specific actions. It is somehow the legacy of German thought. Mickiewicz could not fully appreciate that tradition. It comes from his radical irrationalism and faith in mysticism. Mickiewicz's disdainful and frivolous attitude towards the limitations and strictness of the philosophical method was his own limitation. Total embodying faith in which he saw freedom was the weakness of Polish culture.

Cieszkowski, however, values German idealism, especially the Hegelian dialectic method that he used to conduct an immanent critique of Hegel's philosophy, in an attempt to "overcome the limits of all philosophy past and present", to process abstract reflectiveness into action. ${ }^{20} \mathrm{He}$ was one of many commentators and critics of the Hegelian system. Dembowski, commenting on the situation in 1843, states that, "No firm progress has been made (except by Cieszkowski, who might do it) in areas of expertise", ${ }^{21}$ and Cieszkowski was the one to build the new philosophical system, which would be an emanation of the Hegelian system. Cieszkowski wanted to transform abstract reflectiveness into life by establishing a corrected version of the system in philosophy of action (filozofia czynu) ${ }^{22}$. This would involve: 1) adding future to the organism of history so it would become an integral part; 2) changing the value of an independent unit, from a tool through which reason works to being self-aware,

\footnotetext{
${ }^{16}$ WALICKI [1970], p. 29.

${ }^{17}$ Loc. cit.

${ }^{18}$ It was announced in "Globe" in 29 of January, 1832.

${ }^{19}$ WALICKI [1970], p. 21.

${ }^{20}$ KOZŁOWKI [1999], p. 11.

${ }^{21}$ DEMBOWSKI [1955], p. 397.

${ }^{22}$ Ibid., p. 406.
} 
creating people; 3 ) changing the arrangement of categories present in history. Cieszkowski wanted to apply categories that can be traced in nature and spirit to Hegel's historiosophy, which for him is insufficient. The Polish author rearranges the order of history and claims that it can be adjusted with three categories: a) the past, an age of beauty which is associated with emotion and was developed in Antiquity through the perfection of art; b) the present, the age of thought, which is associated with thinking and has developed throughout Christianity through the perfection of knowledge in philosophy; c) the future, the age of goodness, which is associated with action (act) and will be "developed in the world of the future, when knowledge will come to life while becoming an act and will give birth to absolute virtue", ${ }^{23}$ all of the acts are going to be conscious, and people will become not thinking or feeling beings, but creative ones; it will be the time of universal reintegration. Just as Christianity was the age of humanGod, the third one will become the age of Godlike-humanity. This religion will be the highest development of the "eternal religion" in the form of Paraclete Religion. ${ }^{24}$ Liturgy will become art, science will replace dogma etc. There will be no priests, only artists, officials and scientists - all working for the public good. $^{25}$

Kozłowski points out that Cieszkowski uses philosophy, its dialectic method, as merely an instrument. It loses its independence. "Philosophy itself, even in its most perfect shape given to it by Hegel, becomes a historical phenomenon, essentially incapable of expressing the sense of history as a whole. It must, therefore give way - together with art - to another realm of absolute spirit, i.e. religion". ${ }^{26}$ It serves as a means, and not as a goal itself. Cieszkowski becomes Hegel's competitor instead of a teacher of the practical use of dialectics. ${ }^{27}$ By establishing the historiosophical problem of Slavs on the level of absolute spirit, a problem which in Hegel's system is solved within the framework of objective spirit, Cieszkowski wants to change an individual's own influence on history from a tool of "cunning reason", to a "conscious and independent" executor of principles. Yet the shift only establishes how individuals might view the content and does not answer the question: what will the content of the future be? Kozłowski comments on this attempt that "instead of concrete analyses of actually functioning institutions of ethnicity, Cieszkowski presents mostly sublime declarations, wishful thinking and expectations that individuals will become 'artists, scientists and public people". ${ }^{28}$ In conclusion Cieszkowski's

\footnotetext{
${ }^{23}$ Ibid., p. 408.

${ }^{24}$ Paraclete $(\pi \alpha \rho \alpha \dot{\kappa} \lambda \eta \tau o \varsigma)$ means advocate or helper. In Christianity, the term paraclete most commonly refers to the Holy Spirit.

${ }^{25}$ WALICKI [1970], pp. 67-69.

${ }^{26}$ KOZŁOWKI [1999], p. 12.

${ }^{27}$ Ibid., p. 13.

${ }^{28}$ Ibid., p. 14.
} 
attempt did not fulfill its obligation. Despite efforts to expand the organism of history, by shifting the categories and setting historiosophy as a realm of absolute spirit, only to extend the dialectic competencies that could predict future, he overestimated the possibilities of his programme. ${ }^{29}$

Nonetheless, Dembowski had a deep respect for Cieszkowski's attempt to open the prospect for the future via a reinterpretation of Hegelian system. Much like the Count, Dembowski at the very beginning accepts Hegel's thought as an absolute reference point. In his first article, the author specifies significant problems which will be held later in his writings. He defines philosophy as Knowledge, which thanks to Hegel is no longer a love of knowledge (wisdom) but autonomous Knowledge itself. In addition, it enriches all human activities by giving them meaning. ${ }^{30} \mathrm{He}$ also complains that Poles are not interested in philosophy, and don't like to think at all. During 1842-1843, he published the culture-forming "Przegląd Naukowy" in which he promoted philosophy, gave lectures on the Hegelian system and on problems with our philosophical passivity.

In his text Present idealistic position, Dembowski states that the ultimate purpose of human existence is the happiness of others. That happiness can only be realized in a community. This understanding comes from within and is given through God's love. However, love deprived of thinking is madness. It is necessary to find a thought that will elevate like a spring all cognitive functions to knowledge. Knowledge is the motion and force of the world. "Progress is the nature of thought (...) the very thought itself". ${ }^{32}$ Thought must objectify itself and that process is necessary to produce self-consciousness. At this point he states that philosophy requires being Christian, ${ }^{33}$ but in contrast to Cieszkowski, he does not simply leave the future of societies in God's hands but underlines Christianity's value as mature thought. In order to create community, the knowing of truth has to be combined with educated feeling. ${ }^{34}$

Dembowski's own intellectual source of inspiration was, besides Hegel's system, philosophy of action. He critiques the arrangement of the categories proposed by Cieszkowski (emotion linked with beauty, thinking linked with truth and action linked with goodness). He states that emotion corresponds not with beauty, but with life, the primary unconscious act, whereas beauty is created only by the harmony of emotional engagement and thought ${ }^{35}$. As for the basis for the whole

\footnotetext{
${ }^{29}$ Ibid., p. 15.

${ }^{30}$ DEMBOWSKI [1955], p. 3-4.

${ }^{31}$ Ibid., p. 27-36.

${ }^{32}$ Ibid., p. 34.

${ }^{33}$ Ibid., p. 37.

${ }^{34}$ Ibid., p. 39-40.

${ }^{35}$ Ibid., p. 408.
} 
system, chosen categories have to be designed as a harmonized whole. "The most perfect of them must be unity with the previous two - action is only a symptom of a conscious thought, not the unity of thoughts and feelings" ${ }^{\text {"36 }}$ because that is creation. Dembowski sees what Cieszkowski omitted - if philosophy is to retain its autonomy, and not become a means to some goal, it has to remain at the level of absolute spirit. If philosophy's goal is to determine the historical goal of a nation, philosophy ceased to be itself, and it becomes only a justifying rhetorical technique.

He gives a preliminary draft of his own system in the article Position of the future of philosophy, where he presents the philosophy of creation that reveals the nature of all elements(emotion, thought, creation) thanks to Hegelian analysis. It is progress. Thus, he makes an attempt to create a proposition of a System of Knowledge that would be based on the mentioned elements, would take account of them in relation to the entire system as an organic whole and would determine which fields they correspond with. "Creation is harmonized emotion and thought, creation is identical with being" $" 37$ and through that principle the whole system will be developed. 1) Emotion as the most detached moment of creation, the most abstract one, not realized yet is logic; 2) a higher degree than emotion, its negation is thought - passed into reality. Thought knows but does not know that it knows, so its nature; 3) only the fully developed thought that knows and feels that it knows what and why it feels is creation - the field of the spirit. ${ }^{38}$ All of those domains continue to be analogically developed, for instance: "thought as a thought is: 1) emotion, 2) thought, 3) creation.", and then in the footnote: "thought as a thought being creation is completely different to creation as creation being thought; the first one is organism, and the second knowledge". ${ }^{39}$ But, what is most interesting is the author's arrangement of history. After dividing it into 1) people of the east; 2) Hebrews, Greeks, Romans; 3 ) the history of Christian people,$^{40}$ he says of the last period, "the third period will be the future. It will develop according to the thought divisions, and finally knowledge will go in life". ${ }^{41}$ He proposes this fractal historiosophical system of history that is never closed, always in movement and progressing towards the next whatever. He does not promote Polishness nor Slavs. He only describes the significance of history and states that the vacant position is up for grabs, history has not finished yet.

\footnotetext{
${ }^{36}$ Ibid., p. 409.

${ }^{37}$ Ibid., vol. III, p. 123.

${ }^{38}$ Ibid. p. $124-125$.

${ }^{39}$ Ibid., p. 126.

${ }^{40}$ That has its own inner divisions

${ }^{41}$ DEMBOWSKI [1955], vol. III, p. 134.
} 
Dembowski's Slavic promotion is not an element of absolute spirit, but a necessary part of creating an environment for the creation of philosophy. It is an outer-philosophical condition of possibility philosophy being created by Poles. His attempt was not about predicting, or even creating via Polish national philosophy or messianism, the real future of Poland. He referred to deeply rooted, already existing Western philosophical tradition and lively feelings evoked by national sentiments. His heroic, truly romantic attempt was rather to project and create a new space for future Polish thought. Its aim was the Polish new intelligent class that didn't yet exist but which would create modern society. Through all of his pedagogical attempts he tried to update the Polish soul into philosophy and independency. His attempt was about asking what philosophy is, at what point it currently is, what its competencies are and how we can justify its existence with our participation in the future. He does not ask wishfully how the future will look, but he tells us: if we want it to be with Polish philosophy, then we should create it. "Do not underestimate the work of centuries," Dembowki states, "(...) let's be their disciples, and when their knowledge becomes ours, let's look at ourselves and through knowledge that already for us is true let's expand, and we shall be on our way towards absolute progress". ${ }^{43}$

Both French and German philosophical traditions were, as traditions, rooted in some sort of social environment. The nineteenth century was powered by the third state, by the bourgeoisie, which, at that time, did not exist in Poland. Dembowski was a landowner, Polish landed gentry, but the tradition he referred to was bourgeois. Western Europe built its thought on the basis of an existing or emerging middle class society. Dembowski built on a void. He made an attempt to build the basics for intellectual independence, which was not only intellectual independence, but Polish intellectual independence that was not fixated with the privileged God's chosen nation, but simply with a self-conscious nation. The category of creation that is identical with being, a pedagogical, almost Enlightenment-like attempt to promote philosophy, the creation of new Polish philosophical dictionary, and later social criticism, were a great base for the announced philosophy of the future. If not for the author's premature death, he probably would have made this the basis for the system objection against social evolutionism, a vision of the social doctrine of creativity as a system to promote an active, conscious participation in the creation of society and the collective determination of its future. What Dembowski was trying to do was, as Brzozowski would call it, the impossible work or the impossible creation. He wanted to single-handedly create what should be the work of an entire nation, its self-consciousness.

\footnotetext{
${ }^{42}$ Ibid., p. 109-111.

${ }^{43}$ Ibid., p. 111.
} 


\section{An attempt to update}

From the perspective of a person that made an attempt to create a philosophy that would be both established in the contemporary philosophy of its time and remain an integral character of a nation, we can grasp some interesting intuitions. However, not all of these elements have to remain relevant, as philosophical qualities today. The most interesting is the question of the philosophical future: the immanent trace of its progress and its independence. Thus, the question about progress emerges. This can go in one of two ways: 1) philosophical progress might be in relation to other fields of studies i.e. religion, history or literature but most likely science, 2) philosophy will try to retain its integrity and its indetermination (it's a little bit too late for independence). In the first case, we might predict that the engagement will be its determination. Science with its intense expansion, technical background, well-functioning international scientific community, well established division of labor, and its goal: specified and tangible success will dominate philosophical claim. Science will probably absorb philosophy, only if it has not happened yet, and its function will be to analyze on a more general level detailed information and build more general scientific theories. In the second case, the question that philosophy asks itself about itself is a question of its progress. It is the question of its future, not in a determined manner but in a creation manner (by creation I do not mean here the recent commonly used and overused understanding of creation as creativity in a marketdetermined way or arbitrarily constructed visions of philosophy of handicraft or housing design, but as a conscious, intentional act, according to some inner logic of the process). To avoid shallowness, thought must examine itself and recognize its own progress. Philosophy must avoid too strong relationships with other fields of knowledge. It cannot lose sight of understanding for its own progress, or else it will become merely a justifying rhetorical technique. In reference to Dembowski and opposite to Smith we might say that the creation of philosophy should be its own creation, self-conscious creation that would be, at least to some extent, independent from the "simple process of modernization". Dembowski's question about philosophy and its self-consciousness is still relevant. It is a purely practical act: philosophy will be what we will make of it. Of course, that is almost an obvious answer. But more important is: what is philosophy and who will answer this question?

\section{References}

BRZOZOWSKI, S. [1910], Legenda Młodej Polski. Studya o strukturze duszy kulturalnej, KPBP, Lwów.

DEMBOWSKI, E. [1955], Pisma, PWN, Kraków, vol. I, III. 
KOZŁOWKI, M. [1999], "Does dialectic retain its cognitive validity also beyond the realm of philosophy? Some remarks concerning Cieszkowski's contribution to corretion of Hegel's philosophy of history", [in:] Acta Universitatis Lodziensis, Folia Philosophica, vol. 13, pp. 11-19.

SMITH, B. [2006], "Why Polish Philosophy Does Not Exist", [in:] Poznan Studies in the Philosophy of the Sciences and the Humanities, vol. 89, pp. 19-39.

WALICKI, A. [1970], Filozofia a mesjanizm, PIN, Warszawa 1970. 